\title{
Plastid Transformation of Wheat Cultivar Using Plastid Expression Cassette Carrying Nitrogen Fixation Genes
}

\author{
Maha M. AlKhazindar", E.T.A. Sayed, Asmaa A. Adlan and \\ Y. El-Sadi \\ Botany and Microbiology Department, Faculty of Science, \\ Cairo University, Egypt
}

\begin{abstract}
C HLOROPLAST transformation in wheat was achieved by bombardment of callus from immature embryos. A wheat chloroplast site-specific expression vector pMY-Wt-nif, was constructed by placing an expression cassette containing neomycin phosphotransferase II (nptII) and nitrogen fixation gene cluster from Clostridium acetobutylicum in the intergenic spacer between trnI and trnA of wheat chloroplast genome. Integration of nitrogen fixation gene cluster in the plastome was identified by polymerase chain reaction (PCR) analysis and Southern blotting using specific sequence of the cassette as a probe. Expression of nitrogen fixation gene cluster was examined by Western blot. The results strengthen the feasibility of wheat chloroplast transformation and also give a novel method for the introduction of important agronomic traits in wheat through chloroplast transformation.
\end{abstract}

Keywords: Chloroplast transformation, Expression vector, Clostridium acetobutylicum

The vast majority of nitrogen atoms in living organisms are derived from the atmosphere by certain species of bacteria and blue-green algae that reduce dinitrogen $\left(\mathrm{N}_{2}\right)$ to ammonia. This process, "biological nitrogen fixation," is of fundamental importance to the ecosystem because organic nitrogen is not completely recycled but is continually lost to the atmosphere as $\mathrm{N}_{2}$ by the action of denitrifying bacteria. Relatively little biological nitrogen fixation occurs in conjunction with the agricultural growth of the major cereal crops-corn, wheat, and rice-or the major forage grasses. To compensate for this nitrogen deficiency, farmers throughout the world use 40 million tons of nitrogenous fertilizers each year (Young, 1992), which are manufactured by energy-intensive processes. Nitrogen fixation is widely but sporadically distributed among both eubacteria and methanogenic archaea (Young, 1992 and Raymond et al., 2004). The current understanding of nitrogenase diversity has been based largely on phylogenetic analyses of nifH and nifD, the nitrogenase structural genes (Zehr et al., 2003 and Henson et al., 2004). Recently, Raymond et al. (2004) performed genomic analyses of nif genes encoding the core components of nitrogenase, including the nifH, nifD, nifK, nifE and nifN proteins. The plastids of higher plants have their own $120-160-\mathrm{kb}$ genome that is present in 1,000-10,000 copies per cell.

*Corresponding author: malkhazi@aucegypt.edu, Tel.: 01062979166 
Engineering of the plastid genome (ptDNA) is based on homologous recombination between the plastid genome and cloned ptDNA sequences in the vector. Manipulations of ptDNA include (1) insertion of transgenes in intergenic regions; (2) posttransformation excision of marker genes to obtain marker-free plants; (3) gene knockouts and gene knockdowns, and (4) cotransformation with multiple plasmids to introduce nonselected genes without physical linkage to marker genes. (Maliga and Svab, 2011).

The success of plastid transformation in any species depends largely on successful DNA delivery to target plastids, transgene integration into the plastid genome followed by selection and regeneration of transplastomic plants. Although plastid transformation is relatively straightforward in species such as tobacco, the process has proved to be less efficient and sometimes impossible in other more economically important crops; for example, with the exception a single report of heteroplasmy in rice (Lee et al., 2006), chloroplast transformation in cereals has not yet been established. It has been hypothesized that this is mainly due to the plastid characteristics in combination with less efficient regeneration characteristics.

The monocistronic translation of nuclear messenger RNAs (mRNAs) poses problems in engineering multiple genes in plants (Bogorad, 2000). Expression of polycistrons via the chloroplast genome provides a unique opportunity to express entire pathways in a single transformation event, such as nitrogen fixation gene cluster. Additionally, chloroplast genetic engineering is an environmentally friendly approach resulting in containment of foreign genes and hyperexpression (Daniell et al., 1998).

In the present paper, we reported the production of fertile, homoplasmic, chloroplast-transformed lines in wheat using a transformation vector that targeted the $\operatorname{trnI} / \operatorname{trn} \mathrm{A}$ region of the wheat chloroplast genome. Stable expression of nitrogen fixation gene cluster in the leaf tissues was confirmed by PCR, Southern blot and Western blot from T1 progeny seedlings. The successful transformation of chloroplasts offered the potential to introduce the functional genes for improving agronomic traits in wheat.

\section{Material and Methods}

\section{Plant material and explant preparation}

Mature caryopses of Triricum aestivum L., an Egyptian wheat variety with high yield production, were immersed initially in $70 \%$ ethanol for $1 \mathrm{~min}$, followed by immersion in 30\% commercial Clorox (containing 5.25\% $\mathrm{NaClO}$ ) supplemented with few drops of Tween 20 for $20 \mathrm{~min}$. and washed several times with sterile distilled water before inoculation. Sterilized caryopses were aseptically germinated in $250 \mathrm{~cm}^{3}$ jars containing $35-40 \mathrm{ml}$ agar-solidified MS medium (Murashing and Skoog, 1962). All the operations and inoculations were

Egypt. J. Bot., 56, No. 1 (2016) 
carried out under strict aseptic conditions in laminar airflow cabinet. The jars were kept in a cooled incubator with diurnal $16 \mathrm{hr}$ light cycle. The temperature was regulated at $25 \pm 1^{\circ} \mathrm{C}$. After ten days of seedlings growth, discs of approximately 3-4 $\mathrm{mm}$ in diameter from the leaves and cutting of 4-5 $\mathrm{mm}$ long sections of epicotyls were used for callus initiation.

\section{Preparation of immature embryos explants}

Immature embryos were isolated from field grown wheat (Triricum aestivum L.) under well-watered conditions (Agriculture Research Center, 2012). Spikes were collected from the plants 12-18 days post anthesis. Caryopses were surfacesterilized using $70 \%$ ethanol for $1 \mathrm{~min}$. and $30 \%$ commercial Clorox supplemented with few drops of Tween 20 for 20 min. then Caryopses were washed four times using sterile distilled water. Immature embryos were isolated from the sterilized caryopses and used for callus initiation.

\section{Induction and maintenance of callus cultures}

Immature embryos and segments of leaves and epicotyls were cultured on sterile Petri dishes ( $9 \mathrm{~cm}$ in diameter) containing $20 \mathrm{ml}$ of solid ( $0.8 \mathrm{~g}$ agarose) MS medium supplemented with $20 \mathrm{~g} / \mathrm{l}$ sucrose, $150 \mathrm{mg} / \mathrm{l} \mathrm{L}$-asparagine and different concentrations of 2, 4-dichlorophenoxyacetic acid (1.0, 1.5, 2.0, $2.5 \mathrm{mg} / \mathrm{l})$ alone or in combination with different 6-Benzyladenine concentrations $(0.5,1.0,1.5 \mathrm{mg} / \mathrm{l})$. Embryos were positioned with the epiblast exposed to the medium. The dishes were incubated in dark at $25 \pm 1^{\circ} \mathrm{C}$ for $13-15$ days. After 30 Days of culture, callus induction frequency $(\mathrm{CIF})$ was calculated as: $\mathrm{CIF}(\%)=($ No. of embryos produced calli) / (Total No. of embryos cultured) $\times 100$. Sub-culturing was carried out after 2 weeks by cutting the induced callus into small pieces $(150 \pm 20 \mathrm{mg})$ and transferring them to fresh MS medium supplemented with $20 \mathrm{~g} /$ sucrose, $150 \mathrm{mg} / \mathrm{l}$ L-asparagine and $2 \mathrm{mg} / 1$ 2,4-dichlorophenoxyacetic acid (2, 4-D).

\section{Construct preparation for bombardment}

$60 \mathrm{mg}$ of gold particles $(0.6 \mu \mathrm{m})$ were placed into a $1.5 \mathrm{ml}$ microfuge tube. One $\mathrm{ml}$ of $70 \%$ ethanol was added to the particles, mixed for $5 \mathrm{~min}$ at room temperature, and then incubated for $15 \mathrm{~min}$. The particles were collected by centrifugation at maximum speed for $5 \mathrm{~min}$, the ethanol was removed and the particles were resuspended in $1 \mathrm{ml}$ sterile $\mathrm{H}_{2} \mathrm{O}$, mixed for $1 \mathrm{~min}$ at room temperature, and then incubated for $1 \mathrm{~min}$. The gold particles were collected by centrifugation at maximum speed for $5 \mathrm{sec}$. The $\mathrm{H}_{2} \mathrm{O}$ wash steps were repeated three times, the supernatant after the fourth $\mathrm{H}_{2} \mathrm{O}$ wash was removed, and then the particles were resuspended in $1 \mathrm{ml}$ of sterile $50 \%$ glycerol. While continuously vortexing the stock solution of gold particles, a 50ul aliquot were transferred to a fresh microfuge tube. The following additives were added: $2.5 \mathrm{ul}$ of plasmid DNA (2.5ug), $50 \mathrm{ul} 2.5 \mathrm{M}$ $\mathrm{CaCl}_{2}$, and $20 \mathrm{ul} 0.1 \mathrm{M}$ spermidine. The microfuge tube continuously vortexed for $3 \mathrm{~min}$, the tube was incubated at room temperature for $1 \mathrm{~min}$. to allow the particles to settle, and then collected by centrifugation at maximum speed for $15 \mathrm{sec}$. The 
supernatant layer was removed and replaced by $140 \mathrm{ul}$ of $70 \%$ ethanol without disturbing the pellet; the ethanol layer was removed and replaced by $140 \mathrm{ul}$ of $100 \%$ ethanol again without disturbing the pellet. The supernatant was removed and replaced with 50ul of ethanol.

\section{Transformation of wheat plants}

The microcarrier was placed in the metal holder of the gene gun apparatus, Biolistic PDS-1000/He Particle Delivery System (Bio-Rad Laboratories, Hercules,CA), using the seating device supplied by the manufacturer. The sheet was washed twice with 6 ul of ethanol.

The prepared gold particle pellet was vortexed for $5 \mathrm{sec}$, while suspension, 6 ul of the particle slurry were quickly transferred and spread in the center of the microcarrier. The ethanol solution containing the DNA-coated particles allowed drying on the microcarrier. The microcarrier was loaded into the gene gun and then used to shoot the callus from a distance of $9 \mathrm{~cm}$.

\section{Regeneration of transgenic plantlets}

After bombardment, the calli were transferred to regeneration medium (4.4 g MS basal medium and $30 \mathrm{~g}$ sucrose, $\mathrm{pH}$ 5.8). When the medium cooled, TDZ (50 mg dissolved in $1 \mathrm{ml}$ of DMSO) was added at different concentrations $(0.0,1.5,2$ and $2.5 \mathrm{mg} / \mathrm{l})$. Calli were left to regenerate at $25^{\circ} \mathrm{C}$ under $16 \mathrm{hr}$ photoperiod for 2 weeks. The regenerated shoots were transferred to the rooting medium ( $2.2 \mathrm{~g} \mathrm{MS}$ basal medium and $30 \mathrm{~g}$ sucrose, $\mathrm{pH} 5.8$ ). The recovery was performed at $25^{\circ} \mathrm{C}$ in the $12 \mathrm{~h} / 12 \mathrm{~h}$ light/dark during regeneration and selection phases.

\section{Confirmation of the vector integration and gene of interest expression}

Transgene integration into wheat plastid genome was confirmed by PCR assay using internal primers I-F (which lands on the nptII gene) and I-R (which lands on the nif gene cluster). Another PCR assay performed using primers O-F (which land on the native chloroplast genome, 500bp upstream of the integration site), and O-R (which lands on the nptII gene). Both PCR reactions were performed in a total volume 50ul each containing 5ul (10x) Taq buffer contains $1.5 \mathrm{mM}$ $\mathrm{MgCl} 2$, 1ul Taq enzyme (5unit/ul), 2ul dNTP mixture (2.5mM), 0.5ul I-F and I-R primer (100 Pmol/ul) or 0.5ul O-F and O-R primer (100 Pmol/ul), 5ul total DNA template and $36 \mathrm{ul} \mathrm{H}_{2} \mathrm{O}$. The reaction mixture was subjected to amplification as following: Initial denaturation of DNA template at $95^{\circ} \mathrm{C}$ for $2 \mathrm{~min}$, followed by 40 cycles of amplification with denaturing at $95^{\circ} \mathrm{C}$ for $1 \mathrm{~min}$. annealing at $60^{\circ} \mathrm{C}$ for $1 \mathrm{~min}$, the extension at $72^{\mathrm{O}} \mathrm{C}$ for $3 \mathrm{~min}$. and the final extension at $72^{\mathrm{O}} \mathrm{C}$ for $10 \mathrm{~min}$.

\section{Southern blot analysis}

Southern blot analysis was performed in order to investigate homoplasmy or heteroplasmy. The preparation of radioactive DNA Probe was performed using Amersham MegaPrime DNA Labeling Kit according to manufacturer instructions. 


\section{Blotting Procedure}

Southern-blot analysis was performed using total genomic DNA isolated from untransformed and transformed leaves. DNA samples (5mg total DNA) were digested with $M l u \mathrm{I}$ and $N h e \mathrm{I}$ restriction enzymes and then were separated by gel electrophoresis on $0.8 \%$ agarose gels.

The hybridization probe was prepared by digesting the chloroplast transformation vector using $M l u \mathrm{I}$ and NheI restriction enzymes.

\section{Hybridization}

The prepared probe was denatured by boiling at $100^{\circ} \mathrm{C}$ for $5 \mathrm{~min}$, and then chilled on ice for $5 \mathrm{~min}$. The probe was added to $5 \mathrm{ml}$ hybridization solution, and then pre-warmed over night at $65^{\circ} \mathrm{C}$. The membrane was washed two times with $100 \mathrm{ml}$ of a pre-warmed solution of $1 \times \mathrm{SSPE}, 0.1 \% \mathrm{SDS}$ at $65^{\circ} \mathrm{C}$ for $20 \mathrm{~min}$, rinsed in $2 \times$ SSPE, placed on 3MM paper wetted with $2 \times$ SSPE and then sealed in a plastic bag. The pattern of hybridization was visualized on X-ray film by autoradiography using Kodak BioMax MS film.

\section{Western blot analysis}

The expression of the introduced $n p t I I$ gene was authenticated using Western blot analysis The cell lysate from transformed and wild-type wheat leaves were extracted and prepared for analysis using sodium dodecyl sulphatepolyacrylamide gel electrophoresis (SDS-PAGE) according to Sambrook et al. (1989). The separated proteins were transferred onto a $0.2 \mu \mathrm{m}$ Trans-Blot nitrocellulose membrane by electroblotting in Mini-Transfer Blot Module at $80 \mathrm{~V}$ for $45 \mathrm{~min}$. in Transfer. The membrane was placed in blocking solution and incubated for an hour at room temperature in a shaker. The membrane was hybridized with polyclonal anti-nptII serum and incubated for $2 \mathrm{hr}$ at room temperature in a shaker. The hybridizing peptides were detected using horseradish peroxidase-linked secondary antibody. Blots were washed three times with PBST for $15 \mathrm{~min}$. each time and then washed with only PBS for $10 \mathrm{~min}$. Finally, $750 \mu \mathrm{l}$ of $2 \mathrm{x}$ Stable Peroxidase Solution and $750 \mu \mathrm{l}$ of $2 \mathrm{x}$ Lumi-Phos WB chemiluminescent reagent was poured over the membrane and a film was developed to visualize the bands.

\section{Evaluation of gene of interest expression}

Percent leaf organic nitrogen on a dry weight basis was determined for each plantlet with a Kjeltec Auto 1030 Analyzer (Tecator). Dried leaves were ground and digested at $42^{\circ} \mathrm{C}$ for $45 \mathrm{~min}$ in $8 \mathrm{ml}$ of concentrated sulfuric acid and $2 \mathrm{ml}$ of $0.2 \%$ selenium in hydrogen peroxide.

Callus induction and selection

The trials for inducing calli from leaves and epicotyls segments failed for all 
tested media. Necroses of epicotyls and leaves explants were observed after few days of culturing. For immature embryos explants, callus formation was completely inhibited by the presence of $1.0 \mathrm{mg} / \mathrm{l} 2,4-\mathrm{D}$ as the sole growth regulator or in combination with all 6-Benzyladenine (BA) concentrations. $1.5 \mathrm{mg} / \mathrm{l} 2$, 4-D produced poor calli with brown or yellowish brown colors. The highest 2, 4-D concentrations $(2.0$ and $2.5 \mathrm{mg} / \mathrm{l}$ ) alone or in combination with 0.5 and $1.0 \mathrm{mg} / \mathrm{l}$ BA gave the highest significant CIF values (83.96-89.48\%). 2, 4-D at concentration of $2.0 \mathrm{mg} / \mathrm{l}$ was chosen for induction and maintenance of derived calli for the subsequent experiments. BA was excluded, as it did not confer any extra beneficial physiological responses and its exclusion would further reduce the cost of production (Fig. 1).
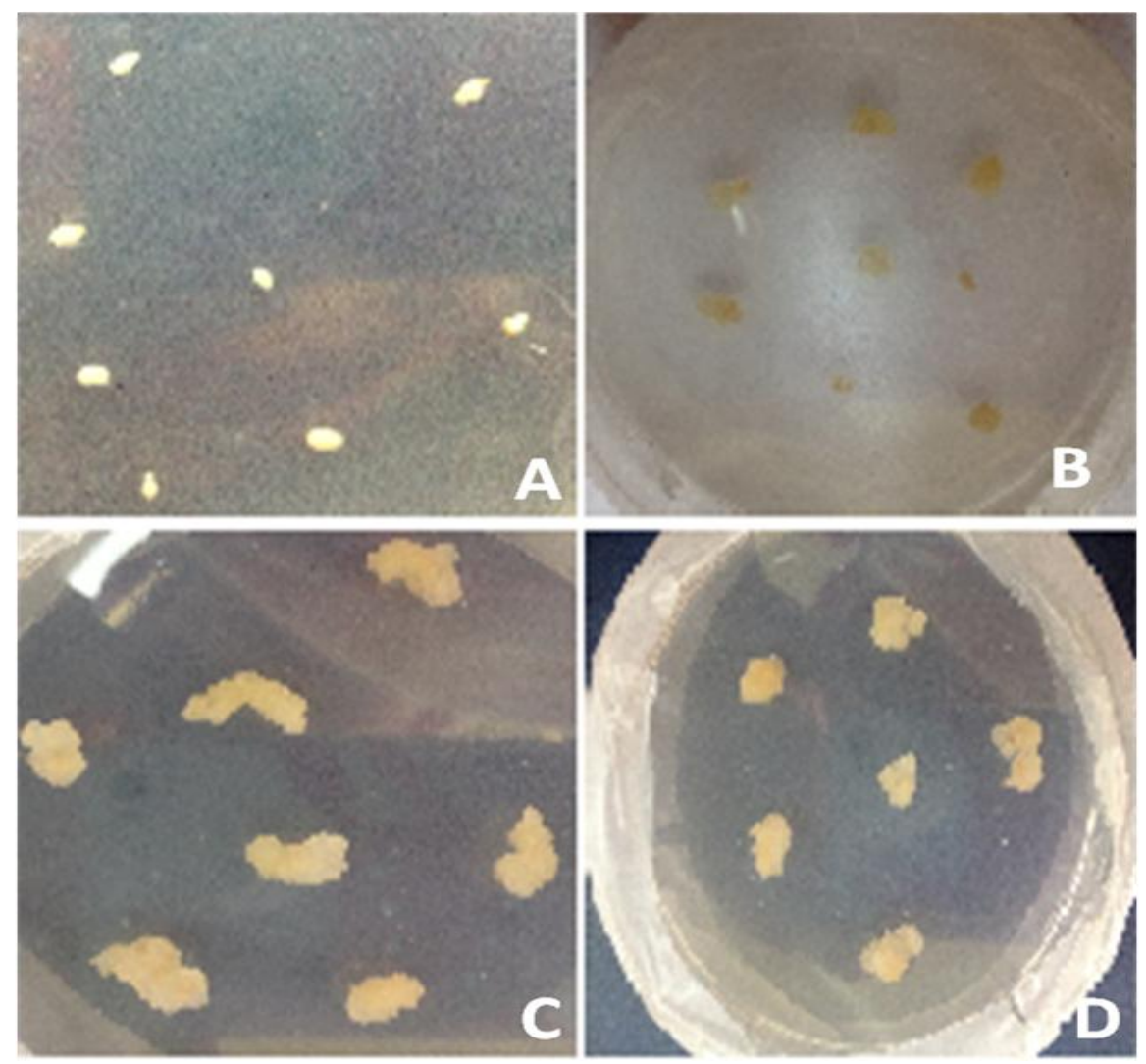

Fig. 1. Initiation and maintenance of callus cultures from Triricum aestivum L. embryos. (A) Wheat embryos cultured on callus induction media. (B) Induced callus from embryo explants. $(C, D)$ Established embryos derived calli.

\section{Regeneration of transgenic plantlets}

After bombardment, the calli were transferred to regeneration medium. The supplement of growth regulators on media apparently facilitated the development of leaves from cultured calli. No adventitious leaves were produced when calli

Egypt. J. Bot., 56, No. 1 (2016) 
cultured on MS media free from growth regulators supplementation. Levels of used hormone represented significant difference of regeneration. The most efficient induction rate and leaves development occurred on MS media containing $2 \mathrm{mg} / \mathrm{l} \mathrm{TDZ}$. As the concentration of TDZ increased over $2 \mathrm{mg} / \mathrm{l}$, the leaves development potential of the calli tended to decrease. Four weeks later, the young shoots were transferred to the selective medium (Fig. 2).

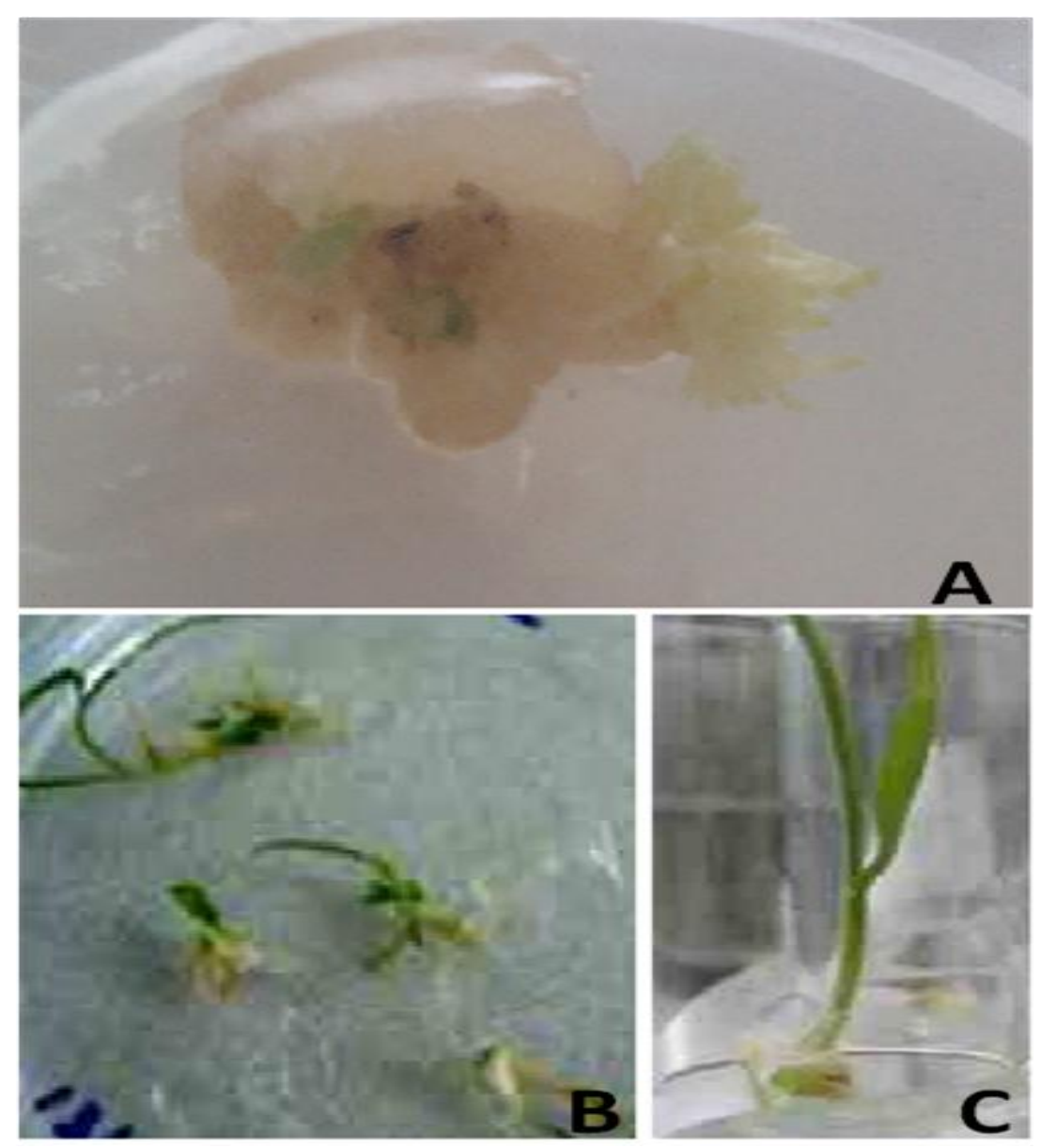

Fig. 2. In vitro plant regeneration from mature embryo of wheat after transformation. (A) and (B), leaves formation; (C), roots formation.

\section{Confirmation of the vector integration and gene of interest expression}

The transgene integration into wheat plastid genome was confirmed by PCR assay using internal primers I-F which lands on the nptII gene and I-R which 
lands on the nif gene cluster, producing $2.6 \mathrm{~kb}$ PCR product (Fig. 3). In order to distinguish between nuclear and chloroplast transgenic cell lines, the external primer $\mathrm{O}-\mathrm{F}$ which lands on the native chloroplast genome, 500bp upstream of the integration site, and $\mathrm{O}-\mathrm{R}$ which lands on the $n p t \mathrm{II}$ gene produced $2.6 \mathrm{~kb}$ PCR product.

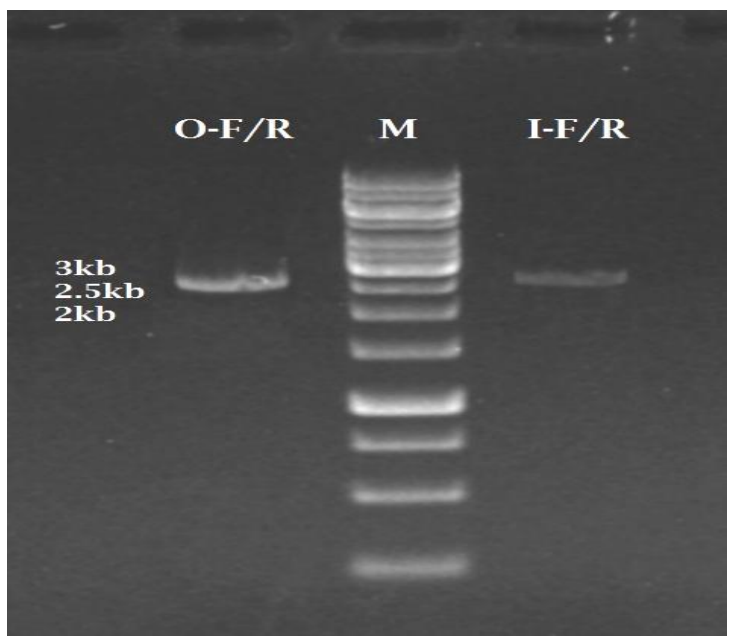

Fig. 3. PCR product $(2.6 \mathrm{~kb})$ from the external primer O-F which lands on the native chloroplast genome, and $\mathrm{O}-\mathrm{R}$ which lands on the $n p t \mathrm{II}$ gene. PCR product $(2.6 \mathrm{~kb})$ from internal primers I-F which lands on the $n p t I I$ gene and I-R which lands on the nif gene cluster.

\section{Southern-blot analysis}

Southern blot analysis was performed in order to investigate homoplasmy or heteroplasmy, using total genomic DNA isolated from untransformed and transformed wheat plants generated from different transgenic cell lines. The hybridization probe resulted in $2.3 \mathrm{~kb}$ hybridization signal (Fig. 4).

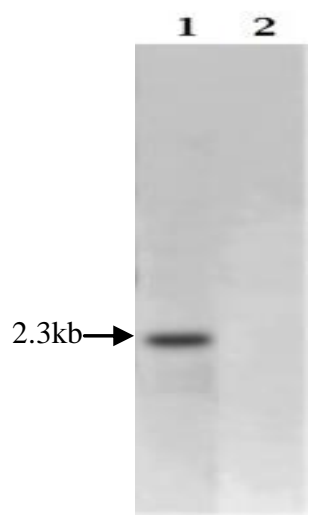

Fig. 4. Southern-blot analysis performed using total genomic DNA isolated from transformed wheat leaves (lane 1) and untransformed wheat leaves (lane 2). The probe used resulted in hybridization signal at the expected size $2.3 \mathrm{~kb}$ in the transformed plants only.

Egypt. J. Bot., 56, No. 1 (2016) 


\section{Western blot analysis}

To further confirm the results of $n p t I I$ gene activity in leaves, western-blot analysis was performed using crude extracts of transformed and untransformed wheat leaves. Fig. 5 shows the detection of $n p t I I$ antigenic peptide.

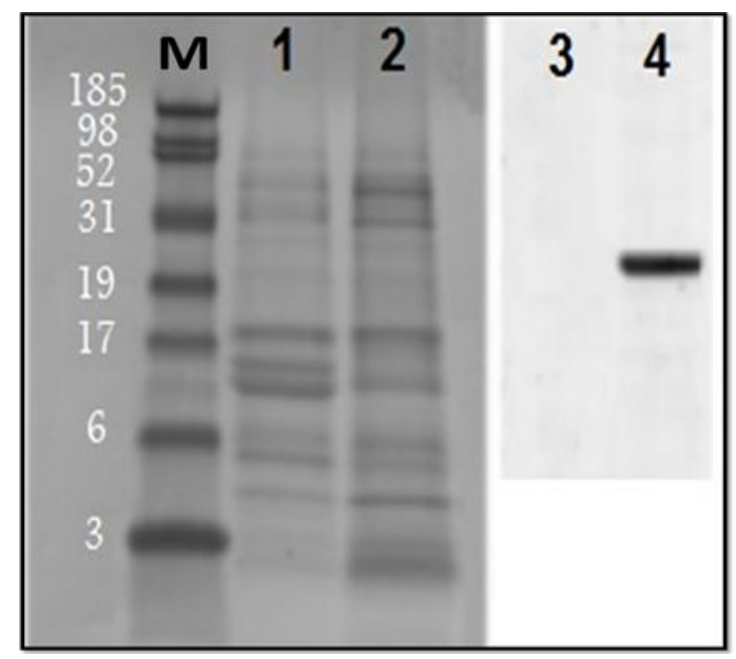

Fig. 5. Western blot analysis using polyclonal anti-nptII serum. Lane 1 and Lane 2 are SDS-PAGE for total protein of untransformed and transformed wheat leaves, respectively. Lane 3 and Lane 4 are $n p t I I$ antigenic peptide detection in untransformed and transformed wheat leaves, respectively.

\section{Evaluation of gene of interest expression}

Percent of leaf organic nitrogen on a dry weight basis was determined (Table 1). The results indicate that the transplastomic wheat plants are able to form more organic- nitrogen than the control wheat plant.

\section{TABLE 1. Determination of the percent of leaf organic nitrogen.}

\begin{tabular}{|l|l|l|l|l|}
\hline & \multicolumn{1}{|c|}{ Control } & \multicolumn{1}{|c|}{ Sample 1 } & \multicolumn{1}{|c|}{ Sample 2 } & \multicolumn{1}{|c|}{ Sample 3 } \\
\hline Flag leaf area $\left(\mathrm{cm}^{2}\right)$ & 3 & 3 & 3 & 3 \\
\hline Leaf nitrogen $\left(\mathrm{mmol} \mathrm{m}^{-2}\right)$ & $12+/-3$ & $19+/-1$ & $18+/-3$ & $17+/-5$ \\
\hline
\end{tabular}

\section{Discussion}

Our present efforts aimed to engineer nitrogen fixation machinery into wheat plant via chloroplast transformation system. In our lab, we constructed wheat chloroplast transformation vector (AlKhazindar et al., 2015). The chloroplast transformation vector, pMY-Wt-nif, was constructed by placing the expression cassettes containing nitrogen fixation gene cluster (nif) and the neomycin 
phosphotransferase II gene (nptII) in the intergenic spacer between the $\operatorname{trn} \mathrm{I} / \operatorname{trn} \mathrm{A}$ intergenic region.

Most cereal crops exhibit natural spectinomycin resistance, because of the presence of point mutations in their 16S rRNAs sequences. In addition, the spectinomycin has been reported to hamper the transgenic callus regeneration in sugar beet chloroplast transformation (Francesca et al., 2009). Therefore, we could not consider aadA gene encoding aminoglycoside 3'-adenylyltransferase as the selection marker gene. The $n p t I I$ gene has been widely used in the wheat nuclear transformation and has also been applied in tobacco and cotton chloroplast transformation. So, $n p t I I$ gene was chosen as the selection gene in this study.

There is no effective regeneration system for monocots' leaves and petioles yet, which is definitely hampering the development of chloroplast transformation in monocotyledonous cereal crops. The calli from rice seed were bombarded for rice plastid transformation and resulted in heteroplasmic fertile plants (Lee et al., 2006). In wheat, we used the callus of immature embryos which were routinely used for nuclear transformation because of their easy in vitro regeneration and capability of obtaining fertile progeny (Jones, 2005). There were no adult chloroplasts in the callus of immature embryos, the protoplastids were spread in the cells and could be bombarded (He and Lazzeri, 2001). Therefore, the delivered foreign genes could be integrated into the genome of protoplastids along with the embryogenesis into adult chloroplasts. Our results are in agreement with Cuiju et al. (2011) who successfully managed to achieve a stable chloroplast transformation of immature scutella of wheat.

The homologous recombination between the two prrn regions and plastome specific regulatory regions in the transformation vector might eliminate the nif gene cluster and nptII expression cassettes that had been integrated into the chloroplast genome, but there were very few relevant studies about this explanation (Daniell et al., 1991 and Wei-Hong et al., 2014). Alternatively, in order to achieve highly efficient regenerable positive plants, it needed to improve the selection pressure in the earlier stages of the targeted tissues.

The marker gene and nif gene cluster integration were confirmed by different PCR assays revealing that our cassette had been integrated into wheat plastome successfully. The Southern blot assay was performed in order to define the heteroplasmy or homoplasmy of our cultivar, resulting in homoplasmic transgenic plants and the fertile transplastomic wheat plants were obtained. The expression of both genes was confirmed by Western blot assay.

In this study, we compared the percent of leaf organic-nitrogen on a dry weight basis for the control plant and three transformed plants, and we found that the transplastomic wheat plants do have a higher percent of organic-nitrogen in their leaves.

Egypt. J. Bot., 56, No. 1 (2016) 
Our results indicate that the transformation machinery of wheat plastome is efficient and our transplastomic wheat is ready for the field studies.

Acknowledgment: This work is supported by Science and Technology Development Fund (STDF) under grant No. 4270, by the Egyptian State Ministry for Scientific Research

\section{References}

AlKhazindar, M., Sayed, E.T. and El-Sadi, Y. (2015) Construction of plastid expression cassette carrying nitrogen fixation genes in wheat. World Journal of Microbiology and Biotechnology. In press

Bogorad, L. (2000) Engineering chloroplasts: an alternative site for foreign genes, proteins, reactions and products. Trends Biotechnol, 18: 257-263.

Cuiju, C., Fei, S., Yi, T., Xuan, Z., Wen, Z., Fengyun, M., Yunyi, L., Javeed, H., Yuesheng, W., Guangxiao, Y. and Guangyuan, H. (2011) Stable chloroplast transformation of immature scutella and inflorescences in wheat (Triticum aestivum L.). Acta Biochim Biophys Sin 43: 284-291.

Daniell, H., Krishnan, M. and McFadden, B. (1991) Transient expression of $\beta$ glucuronidase in different cellular compartments following biolistic delivery of foreign DNA into wheat leaves and calli. Plant Cell Rep., 9: 615-619.

Daniell, H., Datta, R., Varma, S., Gray, S. and Lee, S.B. (1998) Containment of herbicide resistance through genetic engineering of the chloroplast genome. Nat Biotechnol., 16: 345-348.

Francesca, De, M., Yongxin, W., Piergiorgio, S., Sergio, A. and Michele, B. (2009) Top of form bottom of form. genetic transformation of the sugar beet plastome. Transgenic Res, 18: 17-30.

He, G.Y. and Lazzeri, P.A. (2001) Improvement of somatic embryogenesis and plant regeneration from durum wheat (Triticum turgidum var. durum Desf.) scutellum and inflorescence cultures. Euphytica, 119: 369-376.

Henson, B. J., Watson, L. E. and Barnum, S. R. (2004) The evolutionary history of nitrogen fixation, as assessed by nifD. J. Mol. Evol., 58: 390-399.

Jones, H.D. (2005) Wheat transformation: current technology and applications to grain development and composition. J . Cereal Sci. 41: 137-147.

Lee, S.M., Kang, K.S., Chung, H., Yoo, S.H., Xu, X.M., Lee, S.B. and Cheong, J.J. (2006) Plastid transformation in the monocotyledonous cereal crop, rice (Oryza sativa) and transmission of transgenes to their progeny. Mol. Cell, 21: 401-410. 
Maliga, P.I. and Svab, Z. (2011). Engineering the plastid genome of Nicotiana sylvestris, a diploid model species for plastid genetics. Methods Mol. Biol., 701: 37-50.

Murashing, T. and Skoog, F. (1962) A revised medium for rapid growth and bioassays with tobacco tissue cultures. Phyiologia plantarum, 15: 473-497.

Raymond, J., Siefert, J.L., Staples, C.R. and Blankenship, R. E. (2004) The natural history of nitrogen fixation. Mol, Biol, Evol, 21: 541-554.

Sambrook, J., Fritsch, E.F. and Maniatis, T. (1989) "Molecular Cloning: a Laboratory Manual, $2^{\text {nd }}$ ed. Cold Spring Harbor, NY: Cold Spring Harbor Laboratory.

Wei-Hong, X., Cong-Cong, Z., Nai-Sheng, Z., Da-Wei, L., Wei-Dong, Y., Jie-Sheng, L., Ramalingam, S. and Hong-Ye, L. (2014) Construction of Novel Chloroplast expression vector and development of an Efficient Transformation System for the Diatom Phaeodactylum tricornutum. Mar. Biotechnol., 16: 538-546.

Young, J.P. (1992) Phylogenetic classification of nitrogen-fixing organisms. In: "Biological Nitrogen Fixation", Ed by G. Stacey, R. H. Burris \& H. J. Evans. New York: Chapman \& Hall. pp. 43-86.

Zehr, J.P., Jenkins, B. D., Short, S. M. and Steward, G. F. (2003) Nitrogenase gene diversity and microbial community structure: a cross-system comparison. Environ. Microbiol., 5: 539-554.

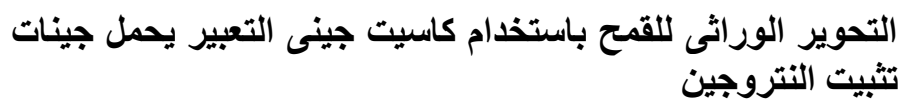

$$
\begin{aligned}
& \text { مها محمد الخازندار ، السيد طارق عبد السلام ، اسماء عدلان، يسري الصادي } \\
& \text { قسم النبات و الميكروبيولوجي - كلية العلوم - جامعة القاهرة - مصر. }
\end{aligned}
$$

الفكرة الرئيسية تعتمد على تحوير بلاستيدات نبات القمح من خلال تعديل الآجنة

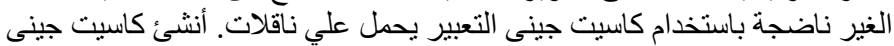

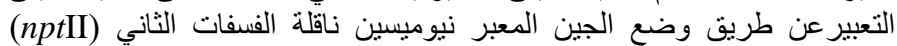

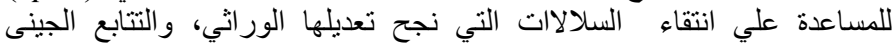

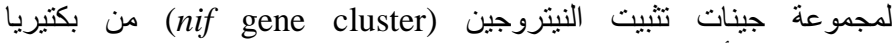

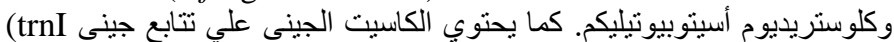

( \& trnA)

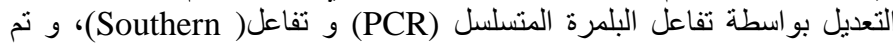

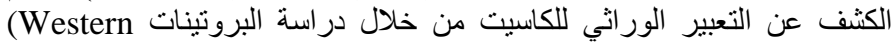

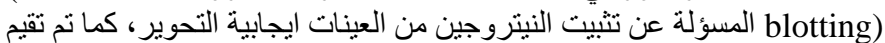

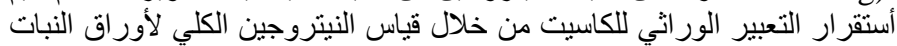

